\title{
ANALYSIS OF RELATIONSHIP AMONG THE FACTORS OF NON- EXCUSABLE AFFECTING DELAY IN CONSTRUCTION PROJECT
}

\author{
Satrio Rekso Wilogo a dan I Putu Artama Wiguna ${ }^{b}$
}

\begin{abstract}
The contribution of the Surabaya construction sector to the growth of the Surabaya economy over the past few decades is highly phenomenal, but many of construction projects in Surabaya are experiencing delays. While much research has been done about the cause of the delay, but the chronic problem of delay time is still very difficult to clearly discovered. The primary objectives of this research are to identify the main factors of non-excusable delay in construction projects and analyze the interdependence relationships of one factor with another. Based on literature, structural model has been developed and then use Partial Least Square to analyze the relationships with quantitative impact value among identified factors. In order to collect the data on the measured attributes, a questionnaire survey was designed in the form of an affirmative question. Respondents for this study are selected from a project manager, head project and director in the Surabaya construction firms were worked on building projects and experienced of dealling delays problem. The results of the research suggest that poor field management is one of the most significant factors significant affecting construction project delay. While path coefficient of poor capability of contractors and improper planning indicated possitive, neither of these two factors has any impact on time delay. On the other hand, poor capability of contractor to be one of the key contributing factors resulting in improper planning and improper planning affecting in poor field management.
\end{abstract}

Keywords: Building Construction; Contractors; Delay; Non-Excusable Category; Partial Least Square; Surabaya

\begin{abstract}
Abstrak: Pertumbuhan sektor konstruksi di Surabaya dalam beberapa dekade terakhir sangat pesat. Namun tidak sedikit dari proyek konstruksi tersebut yang mengalami keterlambatan waktu penyelesaian. Meskipun banyak penelitian telah dilakukan tentang penyebab keterlambatan, namun pola hubungan antar faktor penyebab keterlambatan tersebut masih belum dapat dengan jelas tergambarkan. Penelitian ini bertujuan untuk mengidentifikasi faktor utama non-excusable delay pada proyek konstruksi dan menganalisa pengaruh dari hubungan setiap faktor tersebut. Kerangka model penelitian model telah dikembangkan dari studi literatur dan didapatkan tiga faktor utama yang kemudian dianalisa menggunakan Partial Least Square. Pengumpulan data menggunakan kuesioner yang diberikan kepada kepala proyek, manajer proyek dan direktur teknik di perusahaan kontraktor yang pernah atau sedang mengerjakan proyek gedung di Surabaya dan memiliki pengalaman dalam menghadapi masalah kererlambatan proyek konstruksi gedung. Hasil dari penelitian diperoleh bahwa faktor manajemen lapangan yang buruk berdampak positif signifikan langsung terhadap keterlambatan proyek konstruksi. Sedangkan faktor kemampuan kontraktor yang kurang baik dan perencanaan yang tidak tepat tidak berdampak signifikan terhadap keterlambatan konstruksi walaupun koefisien jalur menunjukkan positif. Di lain sisi, faktor kemampuan kontraktor yang kurang baik, berpengaruh positif signifikan terhadap faktor perncanaan yang tidak tepat dan faktor perencanaan yang tidak tepat, berpengaruh positif signifikan terhadap faktor manajemen lapangan yang buruk
\end{abstract}

Kata Kunci: Konstruksi Gedung; Kontraktor; Kategori Non-Excusable; Keterlambatan; Partial Least Square; Surabaya

\section{INTRODUCTION}

The contribution of the construction sector in promoting economic growth in Indonesia is very large, the construction industry is one of the major industries in Indonesia that its growth rate is increasing from year to year. This is evidenced in 2014, the construction industry is the fourth highest growth rate in Indonesia, with a percentage of 9.88 percent and a growth in the amount of $6.97 \%$. Despite the potential for high growth and employment potential that many construction project in Surabaya faced with the problem delay. By 2015, at least 20 projects of Surabaya government are not completed on time.

While various approaches to the analysis of different

aStudent in the Department of Civil Engineering, Sepuluh Nopember Institute of Technology (ITS), ITS Campus, Sukolilo, Surabaya 60111, Indonesia. Email: satriorekso@gmail.com

${ }^{b}$ Lecturer in the Department of Civil Engineering, Sepuluh Nopember Institute of Technology (ITS), ITS Campus, Sukolilo, Surabaya 60111, Indonesia. Email: artama@ce.its.ac.id

Note. The manuscript for this paper was submitted for review and possible publication on January 23, 2017. This paper is part of the ITS Journal of Civil Engineering, Vol. 32, No. 2, November 2017. (C) ITS Journal of Civil Engineering, ISSN 2579-9029/2017. techniques had been developed, a clear analysis of this chronic issue of time performance of construction projects is still hard to find. Although many studies have published causes and factors affecting schedule and cost performance using numerous techniques $[1,2,3]$ most of these studies failed to examine how the identified causes work together to influence schedule performance in projects, few studies that try to explain how the relationship between the cause of the delay affect each other and how this can affect the project schedule. With the stated situation in the Surabaya construction sector, quantification of the relationships among different causes of delay in Surabaya construction projects is certainly an important topic for investigation.

According to [4] there are three categories of delays, excusable delays, non-excusable delays, and concurrent delays. For the category of non-excusable delays are usually caused by the fault of the contractor, then to limit the scope of this study, will focus on the causes of delay in the eyes of the contractor that is a category of nonexcusable delays. Project delays caused by the contractor requires more attention because of the delay category being the most significant among the causes of other delays [5]. 
Table 1. Variable Research

\begin{tabular}{|l|l|}
\hline \multicolumn{1}{|c|}{ Factors } & \multicolumn{1}{c|}{ Indicators/attributes } \\
\hline \multirow{4}{*}{$\begin{array}{l}\text { Poor Capability of } \\
\text { Contractor (A) }\end{array}$} & A1. Inadequate experience of contractor \\
\cline { 2 - 2 } & A2. Financial constraints of contractor \\
\cline { 2 - 2 } & A3. Incompetence project team \\
\cline { 2 - 2 } Poor Site & A4. Poor communication and coordination \\
\hline \multirow{5}{*}{$\begin{array}{l}\text { Management (B) } \\
\text { Improper Planning } \\
\text { (C) }\end{array}$} & $\begin{array}{l}\text { B1. Ambiguity in specifications and } \\
\text { conflicting interpretation by parties }\end{array}$ \\
\cline { 2 - 2 } & B2. Poor labour productivity \\
\cline { 2 - 2 } & B3. Lack of control over sub-contractor \\
\cline { 2 - 2 } & B4. Poor site management and supervision \\
\cline { 2 - 2 } & B5. Rework \\
\hline \multirow{4}{*}{$\begin{array}{l}\text { C1. Lack of skilled operators for specialized } \\
\text { equipments }\end{array}$} & C2. Delay in material procurement \\
\cline { 2 - 2 } & C3. Poor coordination among parties \\
\cline { 2 - 2 } & C4. Extreme weather conditions \\
\hline
\end{tabular}

Based on this background, it is necessary to do research on the relationship between the factors causing delays in construction projects in Surabaya. The main objective of the study is using data from literature studies to identify the factors causing delays, especially in the non-excusable delays and develop a structural equation model-based variants using Partial Least Square to analyze the relationships influence between latent factors cause a delay so as to provide an overview of the relationship between latent and to minimize errors that result in a delay.

\section{RESEARCH SIGNIFICANCE}

In most studies, priority has been given to identifying the critical causes based on perceptions of different parties in construction. However, quantification of the dependencies of one factor on another and their relative impacts on construction delay in the context of project outcome being influenced by the factors collectively has not been found in many studies. It is important to identify the precise relationship between various key factors of delay and their interactions in relation to overall delay in projects to provide insight to the contractors so that they can take preventive action to avoid delays.

\section{METHODOLOGY}

The type of this research is hypothesis testing (testing research) or often called to the confirmatory study. Confirmatory research is aims to demonstrate and assess or test something to aid researchers in selecting the next action, the study aims to examine the causal relationships between variables. The above review provides the theoretical basis to develop the research framework for this study. It is hypothesized three factors of nonexcusable delay that poor capability contractors, poor site management, and improper planning collectively affect the time performance in projects. Table 1 shows the three latent factors and the respective measured attributes in the hypothetical construct of the research.
In order to explorer the influences of these three key latent factors on construction delay, the research was conducted by the method of Partial Least Square (PLS) sets out three hypotheses as follows:

- Hypothesis 1: Poor capability of contractor influences overall impacts on construction delay.

- Hypothesis 2: Frequency of occurrence of poor site management influences overall impact on construction delay.

- Hypothesis 3: Frequency of occurrence of improper planning influences overall impact on construction delay

While testing the direct influences of the above key factors on construction delay, the interdependence of one factor with another in the structural model is also an important aspect for investigation. Thus the following additional hypotheses have been further developed to test the relative impacts of factors on one another:

- Hypothesis 4: Poor capability of contractor triggers the frequency of occurrence of improper planning.

- Hypothesis 5: Poor capability of contractor triggers the frequency of occurrence of poor site management.

- Hypothesis 6: Frequency of occurrence of improper planning triggers the frequency of poor site management.

A hypothetical diagram of the structural model is presented in Fig. 1.

The arrow represents the direction of the hypothesized influences in the structural model. A questionnaire was used as a survey tool for collecting primary data from respondents. The respondents were asked to assess the perceived influence of the measured attributes in the form of an affirmative question. A five point Likert scale (1= strongly disagree, $2=$ disagree, $3=$ quite agree, $4=$ agree, $5=$ strongly agree) was adopted for guiding the participants to provide their objective response with varying degree of agreement or disagreement. 


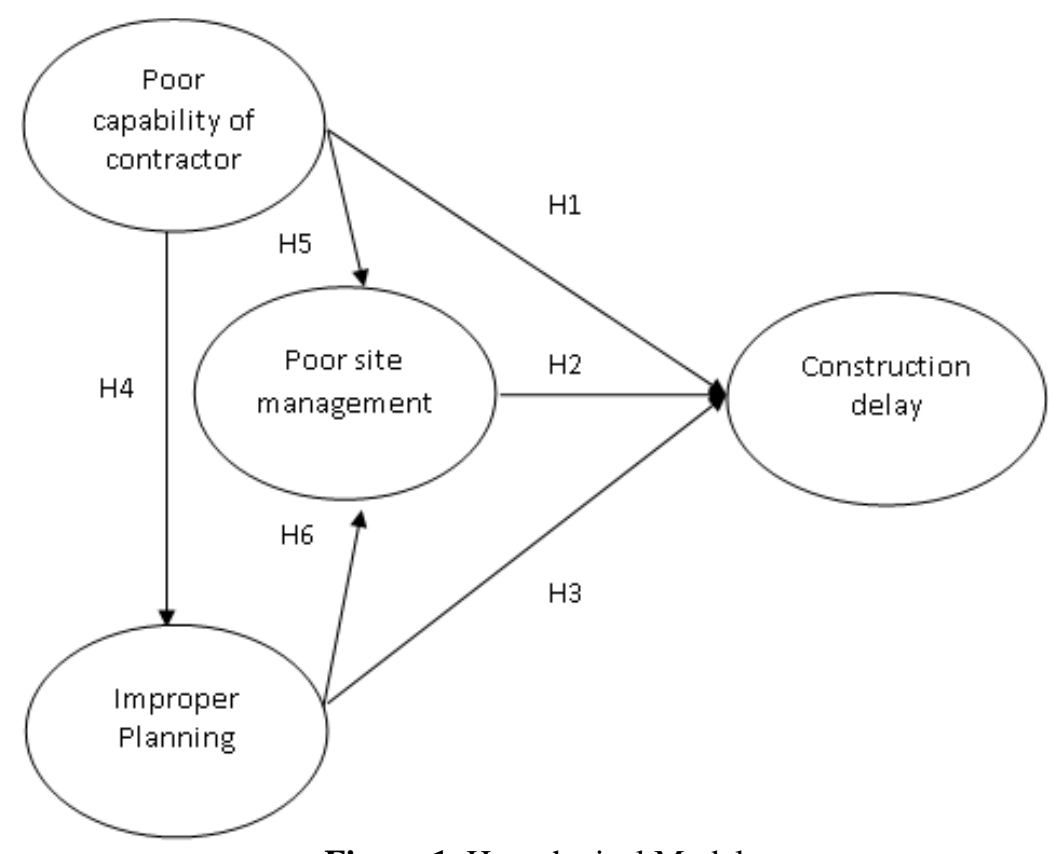

Figure 1. Hypothetical Model

Table 2. Respondents Profiles

\begin{tabular}{|c|l|c|c|}
\hline No. & \multicolumn{1}{|c|}{ Uraian } & $\begin{array}{c}\text { Jumlah } \\
\text { Responden }\end{array}$ & $\begin{array}{c}\text { Prosentase } \\
(\%)\end{array}$ \\
\hline 1. & Responden & 30 & 100 \\
\hline \multirow{5}{*}{2.} & Pendidikan & 0 & 0 \\
& 1. D3 & 23 & 76,7 \\
& 2. S1 & 7 & 23,3 \\
& 3. S2 S3 Sub total & 0 & 0 \\
\hline & 4. S3 & & 100 \\
\hline \multirow{5}{*}{4.} & Pengalaman responden dalam & \\
& melaksanakan proyek konstruksi & & \\
& gedung: & 0 & 0 \\
& 1. S5 tahun $5-10$ tahun & 10 & 33,3 \\
& 2. $10-15$ tahun & 7 & 23,3 \\
& 4. >15 tshun & 13 & 43,3 \\
\hline \multicolumn{2}{|c|}{ Sub total } & 30 & 100 \\
\hline
\end{tabular}

\section{ANALYSIS}

\section{Respondents Profiles}

Respondents for this study are selected from a head contractor organizations in the Surabaya construction sector. All the respondents identified for this study had experience on relatively large construction projects and the problem of delay in Surabaya. Table 2 provides the descriptive statistics of the respondents profiles in terms of their education and experience in the industry.

The minimum required number of samples in PLS is 10 per construct [6], thus a total of 30 questionnaires were sent to the respondents located in 17 firms. Though the sample size is relatively small, the quality of the responses was considered highly reliable for the analysis because of the respondents relevant industry experience, personal interactions and clear understanding of the questionnaire. Among the 30 respondents, the average experience of the respondents was about over 15 years and the average education of the respondents was bachelor degree (S1). It can be seen that most respondents have had experience, and a high level of education that is considered competent or understand the problems of delays in construction projects.

\section{Analysis Measurement Model}

The Partial Least Square have two components, an outer model and an inner model. The outer model is concerned with how well various exogenous variables measure latent variables. Outer model is a measurement model to assess the validity and reliability of the model, through a process of iterative algorithms, parameter measurement model. The second component of a structural equation model is the inner model. The inner model is concerned with modelling the relationships between latent variables, through the process of bootstrapping, T-statistic test parameters obtained to predict the existence of causality. Partial least square 


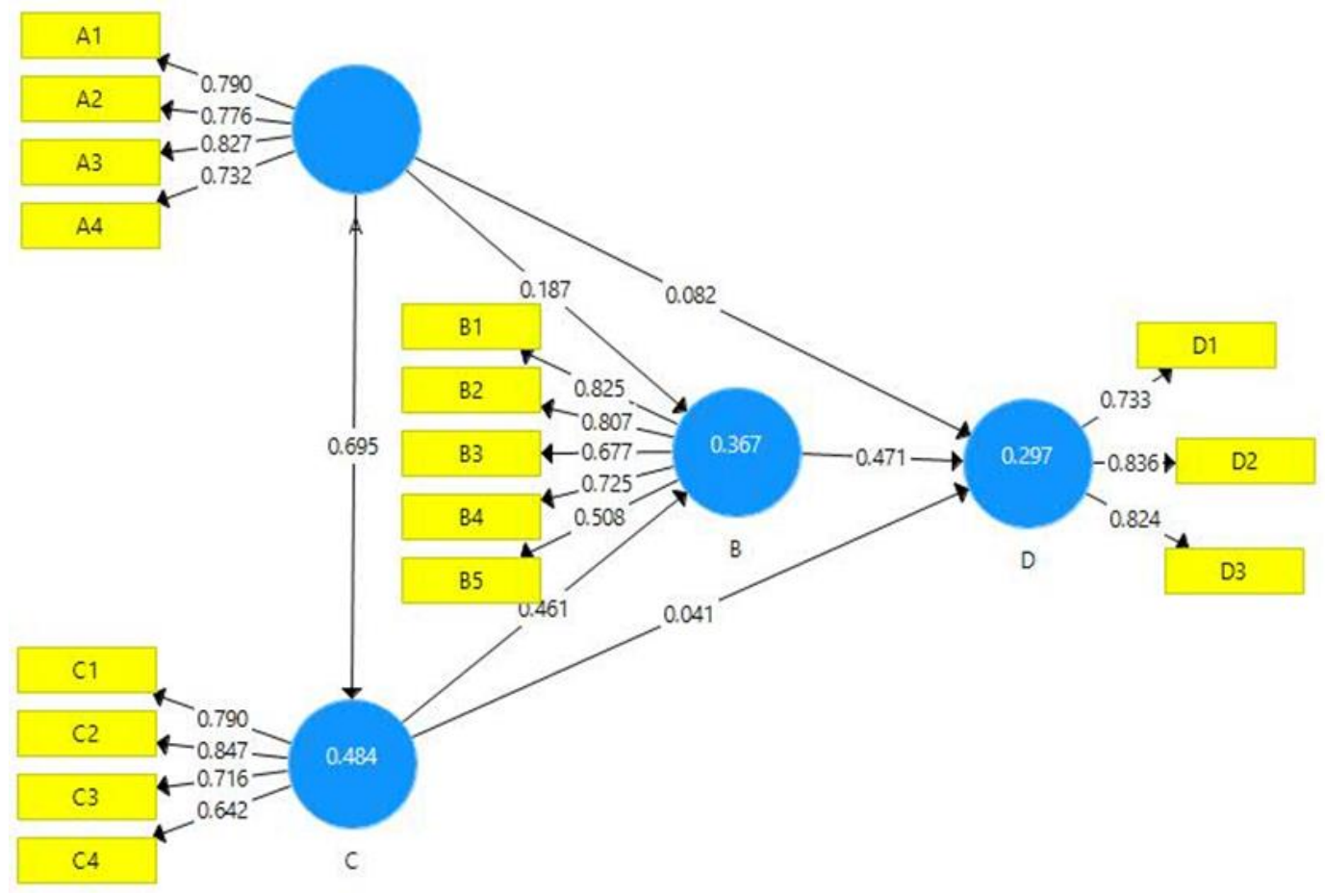

Figure 1. Measurement Model Output

Table 3. Overview Algorithm

\begin{tabular}{|c|c|c|c|c|}
\hline & $\begin{array}{c}\text { Cronbach's } \\
\text { Alpha }\end{array}$ & rho_A & $\begin{array}{c}\text { Composite } \\
\text { Reliability }\end{array}$ & AVE \\
\hline A & 0,788 & 0,795 & 0,863 & 0,612 \\
\hline B & 0,763 & 0,800 & 0,838 & 0,515 \\
\hline C & 0,741 & 0,759 & 0,838 & 0,566 \\
\hline D & 0,716 & 0,726 & 0,841 & 0,638 \\
\hline
\end{tabular}

allow for direct, indirect and correlative effects to be explicitly modelled, unlike standard regression models, which allow for explicit modelling of directs effects only. It is the inner model of Partial Least Square models that enables the analyst to make substantive statements about the relationships between latent variables and the mechanisms underlying a process or phenomenon. Fig. 2 shows the result analysis of measurement model.

\section{Reliability of Constructs}

In order to evaluate the adequacy of the model in relation to the relationships between latent variables and the underlying measured attributes, three different tests were performed. The test are convergent validity, discriminant validity and reliability analysis. Convergent validity is a measure of the internal consistency which is estimated to ensure that the measurement variables provide the true measures of the respective latent variables in entirely. Convergent validity test in the PLS with reflective indicators assessed by the loading factor (correlation between the scores of items with a score constructs) indicators that measure the construct. Rule of thumb used for convergent validity is the outer loading > 0,7 , communality $>0,5$ and average variance extracted $($ AVE) $>0,5$. [6]. Table 3 shows the overview algorithm for each construct. Based on outer loading, communality, and AVE, all the indicators used in this research resulted in a high degree of reliability above the cut-off value so no indicator is removed.

Discriminant validity relates to the principle that indicators the different constructs should not correlated. Discriminant validity occurs when two different instruments that measure the two constructs are predicted not correlated to produce scores that are uncorrelated. Measurement discriminant validity of the measurement model assessed by cross loading measurements. The analysis of cross loadings should result in higher correlation between the measurement variables and the relevant constructs [6]. Table 4 shows that all measurement attributes have loaded with higher correlations on the respective construct in the model and is not related to other construct.

Reliability analysis of the measurements attributes shows the stability and consistency of an instrument to measure a variable. Reliability can be measured by looking at the value Cronbach's alpha and composite reliability. Cronbach's alpha is a lower limit value of the reliability of a construct, while the Composite reliability measure the true value of the reliability of a construct. In this study the reliability test method used is Composite reliability due to better estimate the internal consistency of a construct. Rule of thumb or Composite reliability alpha value should be greater than 0.7 even if the value of 0.6 is acceptable on the exploration research [7]. Following the overview algorithm shows in Table 3, all 
Table 4. Cross Loading

\begin{tabular}{|c|c|c|c|c|}
\hline & $\mathrm{A}$ & $\mathrm{B}$ & $\mathrm{C}$ & $\mathrm{D}$ \\
\hline $\mathrm{A} 1$ & $\mathbf{0 , 7 9 0}$ & 0,455 & 0,492 & 0,347 \\
\hline A2 & $\mathbf{0 , 7 7 6}$ & 0,377 & 0,465 & 0,331 \\
\hline A3 & $\mathbf{0 , 6 2 7}$ & 0,500 & 0,648 & 0,139 \\
\hline A4 & $\mathbf{0 , 7 3 2}$ & 0,227 & 0,562 & 0,298 \\
\hline B1 & 0,555 & $\mathbf{0 , 8 2 5}$ & 0,551 & 0,351 \\
\hline B2 & 0,326 & $\mathbf{0 , 8 0 7}$ & 0,480 & 0,560 \\
\hline B3 & 0,292 & $\mathbf{0 , 6 7 7}$ & 0,498 & 0,393 \\
\hline B4 & 0,318 & $\mathbf{0 , 7 2 5}$ & 0,178 & 0,439 \\
\hline B5 & 0,333 & $\mathbf{0 , 5 0 8}$ & 0,336 & 0,028 \\
\hline C1 & 0,571 & 0,447 & $\mathbf{0 , 7 9 0}$ & 0,136 \\
\hline C2 & 0,682 & 0,329 & $\mathbf{0 , 8 4 7}$ & 0,322 \\
\hline C3 & 0,565 & 0,595 & $\mathbf{0 , 7 1 6}$ & 0,389 \\
\hline C4 & 0,207 & 0,349 & $\mathbf{0 , 6 4 2}$ & $\mathbf{0 , 2 8 1}$ \\
\hline D1 & 0,433 & 0,349 & 0,278 & $\mathbf{0 , 7 3 3}$ \\
\hline D2 & 0,168 & 0,500 & 0,293 & $\mathbf{0 , 8 3 6}$ \\
\hline D3 & 0,267 & 0,425 & 0,332 & $\mathbf{0 , 8 2 4}$ \\
\hline
\end{tabular}

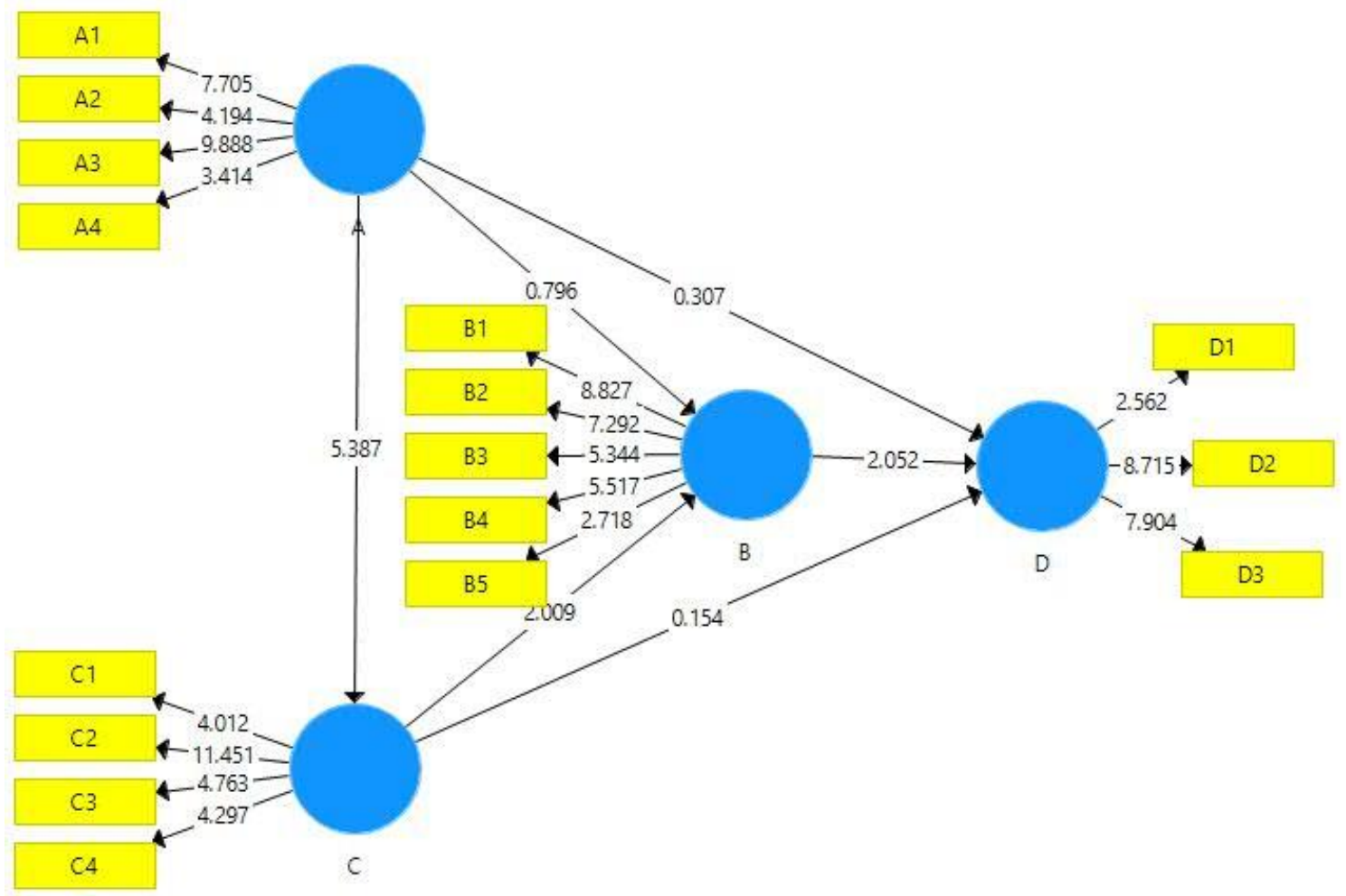

Figure 2. Structural Model Output

composite reliability of each construct above 0.7 so that it can be stated that the measure used in this study is reliable.

\section{Results of The Structural Model and Hypothesis Testing}

The coefficient of path or inner models indicate a level of significance in hypothesis testing. Scores of path coefficients or inner models indicated by the T-statistic, must be above 1.96 for two-tailed hypothesis and above 1.64 for the hypothesis of one-tailed [7]. Fig. 3 shows structural model of this research. The significance of the path coefficients has been tested by analyzing the t- values, standard errors and their corresponding one-tailed significance $(p<0,05)$ is used to study the one-way impacts of one factor over another. Table. 5 shows summary of path coefficient, standard errors and $p$ values.

As seen, out of three primary hypothesis, only one hypothesis $(\mathrm{H} 2)$ were supported at the acceptable significance level of $p$ being less than 0,05. Among the additional three hypothesis (H4-H6) in the construct, two hypothesis are supported (H4 \& H6). Furthermore, if the path with no significant relationships effect excluded, then the end result of relationship influence among the factors will form a line as seen in Fig. 4. 
Table 5. Path Coefficient of Structural Model

\begin{tabular}{|l|c|c|c|c|c|}
\hline & $\begin{array}{c}\text { Original } \\
\text { Sample } \\
(\mathrm{O})\end{array}$ & $\begin{array}{c}\text { Simple } \\
\text { Mean } \\
(\mathrm{M})\end{array}$ & $\begin{array}{c}\text { Standard } \\
\text { Deviation } \\
(\text { STDEV) }\end{array}$ & $\begin{array}{c}\mathrm{T} \\
\text { Statistics } \\
\text { (1-tail) }\end{array}$ & $\begin{array}{c}\mathrm{P} \\
\text { Values }\end{array}$ \\
\hline $\mathrm{H} 1: \mathrm{A} \rightarrow \mathrm{D}$ & 0,082 & 0,061 & 0,268 & 0,307 & 0,380 \\
\hline $\mathrm{H} 2: \mathrm{B} \rightarrow \mathrm{D}$ & 0,471 & 0,490 & 0,230 & 2,052 & 0,020 \\
\hline $\mathrm{H} 3: \mathrm{C} \rightarrow \mathrm{D}$ & 0,041 & 0,081 & 0,266 & 0,154 & 0,439 \\
\hline $\mathrm{H} 4: \mathrm{A} \rightarrow \mathrm{C}$ & 0,695 & 0,685 & 0,129 & 5,387 & 0,000 \\
\hline $\mathrm{H} 5: \mathrm{A} \rightarrow \mathrm{B}$ & 0,187 & 0,244 & 0,235 & 0,796 & 0,213 \\
\hline H6: C $\rightarrow$ B & 0,461 & 0,444 & 0,230 & 2,052 & 0,023 \\
\hline
\end{tabular}

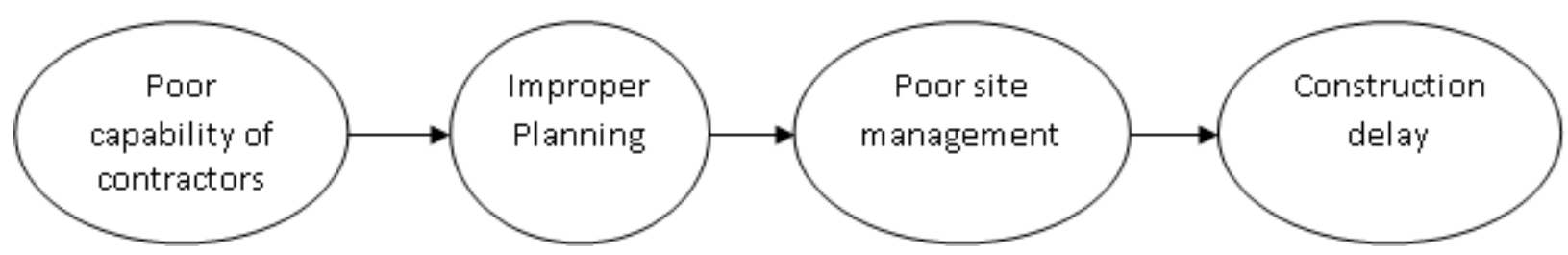

Figure 1. Final Results

\section{DISCUSSION OF RESULTS}

The final model results suggested that only one key factor, poor site management, has direct significant impact on time performance in Surabaya construction industry. Comparing the findings by $[8,9,10,11]$ poor site management was reported to be one of the key factors in terms of ambiguity in specifications and conflicting interpretation by parties, poor labour productivity, lack of control over sub-contractor, rework. The final model results also show that where there are contractors who have poor capability, it is not necessarily going to cause delays, but will go through several intervening variables in advance ie, factors improper planning and poor site management. If a contractor has a poor capability, it can potentially cause the frequency of occurrence of improper planning and potentially also lead to poor field management, and ultimately caused delays too.

Based on a number of interviews with the respondents of the existing condition, shows that many contractors often have financial problems when the contractor is not just one project but many projects at once or within the same time period. Many contractor in Surabaya think that took a lot of projects will increase the benefits and the company name will get prominence, but on the other hand also occur with a high frequency of delays in the project, which ends will also have a negative impact on the company, as entered on the black list of project owners. This can occur because the focus of the company is divided into many projects, but not to think that they owned resource constraints such as financial capability, engineers and others, so the performance or the ability of the contractor that was originally good, over time will decrease.

Thus the practical implications that might be drawn from these findings for contractors is that if a contractor has a poor capability, then they required external factors that can increase performance of planning and management of field. External factors that come from partners such as the support of the owner, consultant or subcontractor supportive and reliable. The support of these partners is needed to cover the weaknesses caused by the contractor, in some studies has also been mentioned that the positive support of the project owner and want to cooperate can be a significant effect on the increase in the commitment and efficiency of the contractor [12]. Therefore to have a good relationship and placing the right partners in a project becomes essential, so expect delays in the construction project problems can be avoided.

\section{CONCLUSION}

Based on the results of this Results of research on the effect of the relationship between the factors causing delays in construction projects, the following conclusions are drawn:

1. The final results show that all lines in the PLS model output showed positive coefficient. Factors poor field management to delay construction projects with a t-value (1-tail) of 1.928 and p values of 0.027 , being the only one factors that influence directly and significantly.

2. The results of the supported hypotheses forming a path between the capability of the contractor effect on improper planning factors with the highest significance value, then from improper planning factors influence on poor site management factors, and poor site management factors have direct impact on construction project delays.

\section{FURTHER RESEARCH}

Based on the analysis and conclusions, the suggestions advanced research that could be addressed in this study are as follows:

1. Further research can be extended by adding another key variable causes delay to the construct models, such as the influence factor of the project owner. 
2. Further research can also be developed with focusing on identification of the field management factors, in relation to the delay in construction projects

\section{REFERENCES}

[1] Assaf, S.A. and Al-Hejji, S., "Causes of Delay in Lanrge Construction Projects", International Journal of Project Management, 2006, 349 - 57.

[2] Oliveros, A.V.O., and Fayek, A.R., "Fuzzy Logic Approach for Activity Delay Analysis and Schedule Updating", Journal of Construction Engineering and Management, 2005, 42 - 51.

[3] Zayed, T.M., and Nosair, I.A., "Cost Management for Concrete Batch Plant Using Stochastic Mathematical Models", Canadian Journal of Civil Engineering, 2006, 1065 - 1074.

[4] Hamzah, N., Arshad, K. I., Tawil, N., and Ani, A. I. C., "Causes of Construction Delay - Theoritical Fraamework",. Procedia Engineering, 2011, 490 495.

[5] Ibironke, O. T., Oladinrin, T.O., Adeniyi, O., and Eboreime. I.V., "Analysisi of Non-Excusable Delay Influencing Contractors Performance in Lagos State, Nigeria", Journal of Construction in Developing Countries, 2013, 53 - 72.
[6] Jogiyanto dan Abdilllah, W, "Konsep \& Aplikasi PLS (Partial Least Square) untuk Penelitian Empiris", BPFE-YOGYAKARTA, 2009.

[7] Hair, J.F. Jr., Black, W.C., Babin, B.J., Anderson, R.E. and Tatham, R.I., "Multivariate Data Analysis", NJ, Pearson Prentice Hall, 2008.

[8] Ahsan, M.K. and Gunawan, I., "Analysis of cost and schedule performance of international development projects", International Journal of Project Management, 2010, 68-78.

[9] Doloi, H., Sawhney, A., Iyer, K.C, and Rentala, S., "Analysing factors affecting delays in Indian Construction projects", International Journal of Project Management, 2012, 479 - 89.

[10] Kadir, M.R.A., Lee, W.P., M.S., Sapuan, S.M., Ali, A.A.A., "Factors affecting construction labour productivity for Malaysian residential projects, Structural Survey, 2005, 42 - 54.

[11] Odeh, A.M., and Battaineh, H.T., "Causes of Construction Delay: Traditional Contracts", International Journal of Project Management, 2002, $67-73$.

[12] Doloi, H., Sawhney, A., and Iyer, K.C., "Structural equation model for investigating factors affecting delay in Indian construction projects", Construction Management and Economics, October 2012, 869884. 